\title{
Sarcoidosis of the breast
}

\section{S BANIK, * PW BISHOP,* LP ORMEROD, $†$ TEB O’BRIEN}

\section{From the Departments of ${ }^{*}$ Pathology, $†$ Medicine, and $\ddagger$ Surgery, The Royal Infirmary, Blackburn}

SUMMARY Sarcoid granulomata were found incidentally in the mammary lobules adjacent to an excised fibroadenoma in a case of sarcoidosis of the breast. The diagnosis of sarcoidosis was established by the radiological finding of bilateral hilar lymphadenopathy, raised concentrations of serum angiotensin converting enzyme and lysozyme, and, finally, by a positive Kveim test.

Sarcoidosis is a multisystem disease with a diverse clinical spectrum of symptoms. Histologically, noncaseating epithelioid cell granulomata in various organs and tissues occur, which undergo either resolution or hyaline fibrosis. ${ }^{1}$

Despite being a multisystem disease the breast is rarely affected in sarcoidosis, as is evidenced by the paucity of documentation of such cases. ${ }^{2-8}$

\section{Case report}

A 28 year old white woman was found to have a smooth mobile lesion $(1 \mathrm{~cm})$ in the upper outer quadrant of her right breast in April 1983 when she was two months pregnant. There was no regional lymphadenopathy or overlying skin lesion: fibroadenoma was clinically diagnosed and the lesion did not change throughout pregnancy. In March 1984 three months after giving birth the lesion was removed.

\section{Results}

Histological examination of the excised lesion showed a typical mixed pericanalicular and intracanalicular

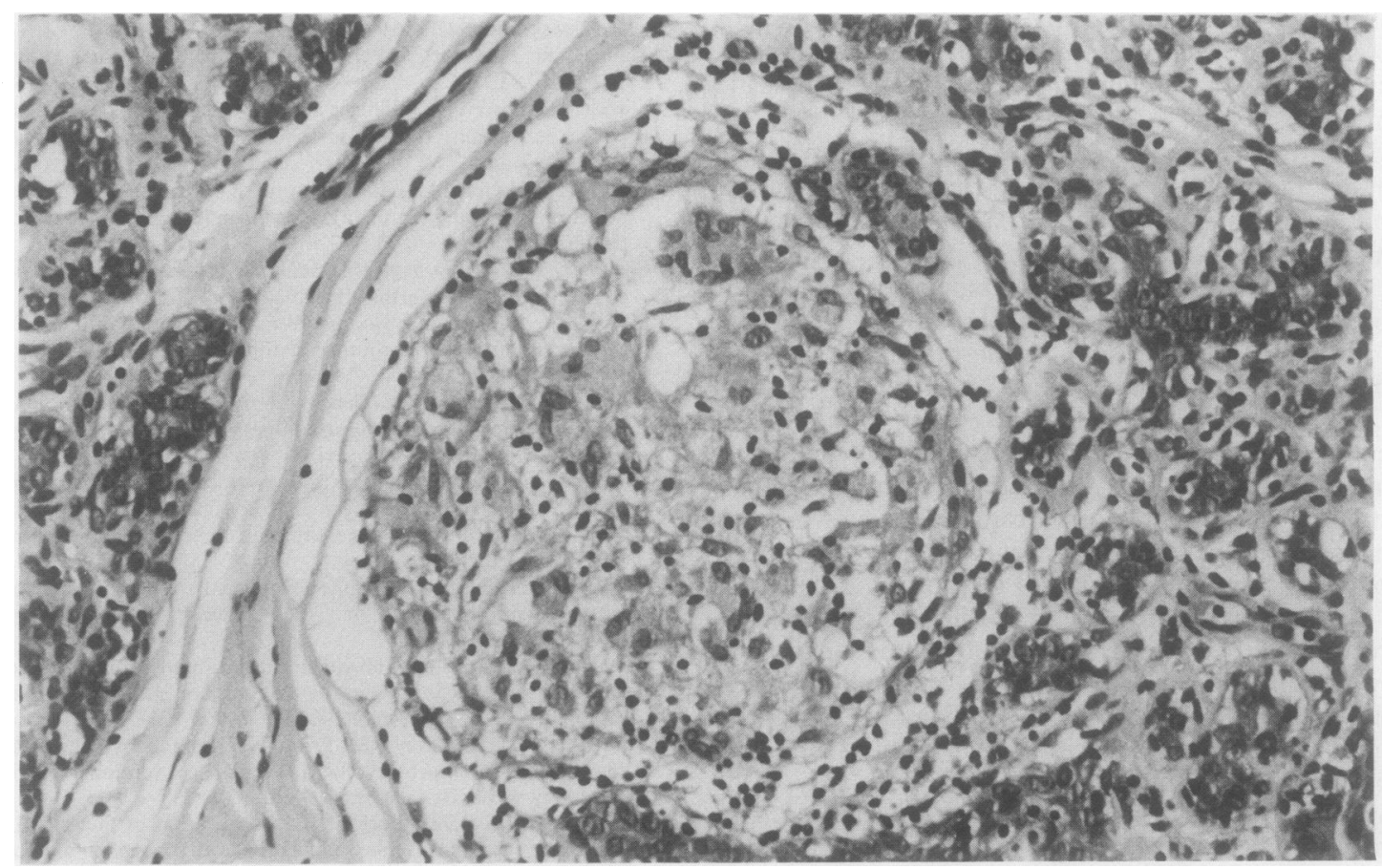

Fig. 1 Well circumscribed epithelioid granuloma in mammary lobule. (Haematoxylin and eosin.) $\times 275$. 


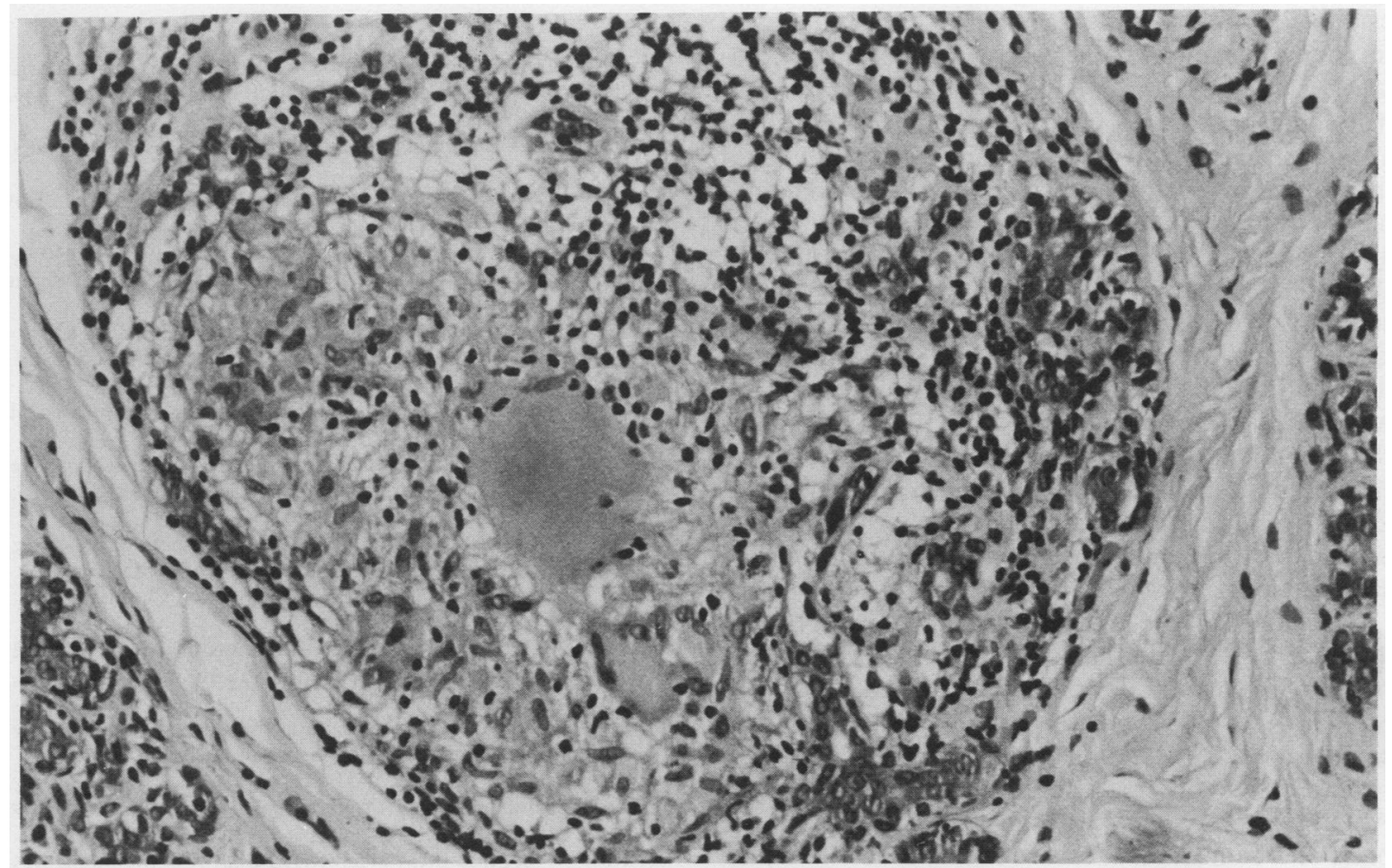

Fig. 2 Epithelioid granuloma showing giant cells with glassy cytoplasm. (Haematoxylin and eosin.) $\times 275$.

fibroadenoma; the mammary lobules adjacent to the fibroadenoma, however, contained several discrete sarcoid granulomata consisting of aggregates of epithelioid histiocytes with some Langhan's giant cells (Fig. 1). There was no acidophilic granular necrosis nor were there any fibrinoid changes in the centre of the granulomata. The giant cells contained abundant amphophilic "glassy" cytoplasm (Fig. 2). Sparse lymphoid cells were present at the perimeter of the granulomata. Asteroid bodies, conchoidal Schaumann bodies, or "yellow-brown" bodies could not be seen. There were no microabscesses. Ductal inflammation, or damage to the ductal epithelium, was absent. Stains for fungi and acid fast bacilli yielded negative results.

She had no other symptoms and no history of erythema nodosum. There was no history of beryllium exposure. A chest radiograph showed bilateral hilar lymphadenopathy with normal lung fields. Spirometry showed a $\mathrm{FEV}_{1} / \mathrm{FVC}$ of $2 \cdot 45 / 3 \cdot 25$ (predicted normal 2.78/3.32 l). Haemoglobin was $14.0 \mathrm{gm} / \mathrm{dl}$ and erythrocyte sedimentation rate $10 /$ first hour. A tuberculin test (Tine) yielded a negative result. The serum angiotensin converting enzyme (ACE) was $96 \mathrm{IU} / \mathrm{ml}$ (normal 5-55 IU $/ \mathrm{ml}$ ) and the serum lysozyme $13 \mathrm{mg} / 1$ (normal $0.8 \mathrm{mg} / \mathrm{l}$ ). Corrected serum calcium concentration was normal at $2.36 \mathrm{mmol} / 1(9.46 \mathrm{mg} / 100 \mathrm{ml})$. There was no clinical evidence of skin, eye, neu- rological, or myocardial sarcoidosis. A Kveim test yielded strongly positive results with multiple epithelioid granulomata.

\section{Discussion}

The presence of sarcoid granulomata in the breast lobules adjacent to an excised fibroadenoma in our patient was an incidental finding. The diagnosis of sarcoidosis was established by the presence of bilateral hilar lymphadenopathy in the chest radiograph, raised serum concentrations of ACE and lysozyme, and, finally, by a strongly positive Kveim test.

Estimation of serum ACE and lysozyme is now an important adjunct in the diagnosis of sarcoidosis. About two thirds of patients with active sarcoidosis do have increased serum ACE; furthermore, consistently high concentrations of ACE have been found in bronchoalveolar lavage aspirates and granulomatous lymph nodes in sarcoidosis. ${ }^{910}$ The source of ACE is thought to be epithelioid cells derived from monocytes in sarcoid granulomata. Serum lysozyme, a lysosomal enzyme, derived from the same cells is not only a useful diagnostic tool but also serves to assess the activity and extent of the disease. ${ }^{11}$

In the differential diagnosis we had to consider granulomatous mastitis, tuberculosis, and fungal infection. Granulomatous mastitis is now a well 
established clinical and pathological entity. It occurs in young women of child bearing age and can simulate a carcinoma. ${ }^{12-14}$ Panlobulitis is an important histological feature of granulomatous mastitis, although microabscesses, ductal damage, and ductal inflammation are often present in this lesion. The nature of granulomatous mastitis is not clear, although similarity to granulomatous orchitis and thyroiditis suggests that autoimmunity, hypersensitivity, or vasculitis may have a role. The sarcoid granulomata in our patient were strictly lobular in distribution, and there were no microabscesses, nor was there any ductal inflammation. Tuberculosis of the breast is rare ${ }^{15}$ and was excluded by the negative tuberculin test, absence of caseation, and negative Ziehl-Neelsen stains for acid fast bacilli. Fungal infection of the breast was also excluded by appropriate special stains.

Sarcoidosis of the breast is extremely rare. The earlier documented cases had simultaneously affected the breast and lymph nodes at the time of presentation. ${ }^{46}$ Standard texts on breast pathology describe only single cases. ${ }^{23}$ Scadding $^{8}$ described one case and reviewed five others, one of which was dubious. Ablative surgery was performed in a patient on the basis of a clinical diagnosis of breast cancer in which histological examination of the breast tumour and regional lymph nodes showed sarcoid granulomata. ${ }^{7}$ In a similar case, in which the patient was also clinically thought to have cancer, fine needle aspiration cytology established the diagnosis of breast sarcoidosis. ${ }^{16}$ We feel, therefore, that sarcoidosis should be considered in the differential diagnosis of granulomatous breast lesions.

\section{References}

${ }^{1}$ Mitchell DN, Scadding JG, Heard BE, Hinson KFW. Sarcoidosis: histopathological definition and clinical diagnosis. J Clin Pathol 1977;30:395-408.

${ }^{2}$ Haagensen CD. Diseases of the breast. Philadelphia: WB Saunders, 1971.

${ }^{3}$ Azzopardi JG. Problems in breast pathology. London: WB Saunders, 1979.

${ }^{4}$ Stallard HB, Tait CBV. Boeck's sarcoidosis. Lancet 1939;i:440-2.

${ }^{5}$ Rigden B. Sarcoid lesion in breast after probable sarcoidosis in lung. Br Med J 1978;ii:1533-4.

${ }^{6}$ Scott RB. The sarcoidosis of Boeck. Br Med J 1938;ii:777-81.

${ }^{7}$ Shinoda M, Nomi S, Iwai K, Izumi T. A case of breast sarcoid. Nippon Geka Hokan 1979;48:404-10.

${ }^{8}$ Scadding JG, Mitchell DN. Sarcoidosis. London: Chapman and Hall, 1985.

${ }^{9}$ Studdy PR, Lapworth R, Bird R. Angiotensin-converting enzyme and its clinical significance: a review. J Clin Pathol 1983; 36:938-47.

${ }^{10}$ Rosen Y, Vuletin JC, Pertschuk LP, Silverstein E. Sarcoidosis: from the pathologist's vantage point. In: Sheldon SC, Rosen PP, eds. Pathology Annual. Connecticut: Appleton Century Crofts, 1979.

${ }^{11}$ Pascual RS, Gee JBL, Finch SC. Usefulness of serum lysozyme measurement in the diagnosis and evaluation of sarcoidosis. N Engl J Med 1973;289:1074-6.

${ }^{12}$ Kessler E, Wolloch Y. Granulomatous mastitis: a lesion clinically simulating carcinoma. Am J Clin Pathol 1972;58:642-6.

${ }^{13}$ De Hertogh DA, Rossof AH, Harris AA, Economou SG. Prednisone management of granulomatous mastitis. $N$ Engl $J$ Med 1980;303:799-800.

${ }^{14}$ Fletcher A, Magrath IM, Riddell RH, Talbot IC. Granulomatous mastitis: a report of seven cases. J Clin Pathol 1982;35:941-5.

${ }^{15}$ Apps MCP, Harrison NK, Blauth CIA. Tuberculosis of the breast. Br Med J 1984;288:1874-5.

${ }^{16}$ Bodo M, Dobrossy L, Sugar J. Boeck's sarcoidosis of the breast: cytological findings with aspiration biopsy cytology. Acta Cytol 1978;22:1-2.

Requests for reprints to: Dr S Banik, Consultant Histopathologist, Royal Infirmary, Blackburn BB23LR, England. 